\title{
JUURNAL.RU
}

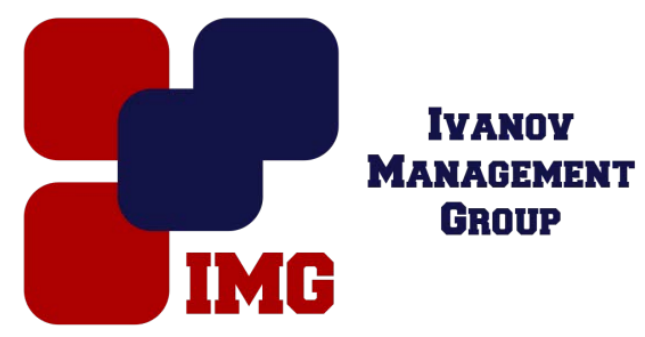

Усякина А.А., Бондаренко С.И. Институт сервиса, туризма и дизайна (филиал) федерального государственного автономного образовательного учреждения высшего образования «Северо - Кавказский федеральный университет»в в. Пятигорске Пятигорск, Россия

doi: 10.18411/lj-30-11-2016-4-11

idsp 000001:lj-30-11-2016-4-11

\section{Мировая практика инклюзивного образования в высшей школе}

\section{Аннотация}

В статье раскрывается понятие инклюзивного образования. Рассматривается международный опыт работы в общем и специальном образовании. А так же увеличение возможностей образования инвалидов в мировой практике и в Российской Федерации в частности.

Ключевые слова: образование, право, инклюзия, инвалиды, условия обучения, способности, особые потребности, возможности, право выбора.

«Для того, чтобы было легко жить с каждым человеком, думай о том, что тебя соединяет, а не о том, что тебя разъединяет с ним» Л.Н.Толстой.

Право на образование - это одно из основных прав любого человека, и этого права нельзя лишать никого. Это - ядро образования для всех. Это необходимо для дальнейшего развития. Ведь человек не сможет пользоваться ни одним из гражданских, политических, экономических и социальных прав до тех пор, если он не имеет образования.

Право на образование - это всемирно признанное право. Оно прописано во Всеобщей декларации прав человека 1948 года и принято во многих детально разработанных документах Организации Объединенных Наций и ЮНЕСКО. Условия в Международном соглашении по экономическим, социальным и культурным правам 1966 года, в статьях 28-30 Соглашения по правам детей 1989 года и другие документы, такие как недавно принятые Соглашения по правам людей-инвалидов, дают основания для нормативного действия и 
отчетливую ссылку на важность приведения инклюзивной системы образования в жизнь.

В течение нескольких сотен лет система образования во всем мире четко разделяла детей на обычных и инвалидов, которые практически не имели возможности получить высшее образование и реализовать свои способности, так как их не брали в учреждения, где обучаются нормальные дети. Несправедливость данной ситуации весьма очевидна. Ведь дети с особенностями развития должны иметь возможность на получение образования наравне с другими детьми. Опыт показывает, что из любой жесткой образовательной системы какая-то часть детей выбывает, потому что единая система не способна удовлетворять индивидуальных потребностей таких детей в обучении. Таким образом, возникла потребность во внедрении такой формы обучения, которая создаст им приемлемые условия обучения - инклюзивное образование.

Инклюзивный подход представляет собой понимание различных образовательных потребностей детей и предоставление им услуг в соответствии с необходимыми потребностями через более полное участие в образовательном процессе, а также привлечение общественности и устранение дискриминации в системе образования. Другими словами, инклюзивное образование - это создание оптимальных условий для совместного обучения детей с ограниченными возможностями и их здоровых сверстников.

Интеграция «проблемных» детей в учреждения высшей школы - это закономерный этап развития системы особого инклюзивного образования в любом государстве мира, это процесс, в который вовлечены все высокоразвитые страны, в том числе и Россия. Государствам следует признавать принцип равных возможностей в области высшего образования для молодежи и взрослых, имеющих инвалидность, в интегрированных структурах. Одна из важных обязанностей этих государств - обеспечивать включение образования инвалидов в качестве неотъемлемой части в систему общего образования.

Очень точно ганский дипломат, секретарь ООН Кофи Аннан в далёком 1998 году произнес такие слова, которые сегодня понимаются как призыв к инклюзивному образованию: «Образование - право каждого человека, имеющее огромное значение и потенциал. На образовании строятся принципы свободы, демократии и устойчивого развития... нет ничего более важного, никакой другой миссии, кроме образования для всех...»

Инклюзивное (франц. inclusif - включающий в себя, от лат. include заключаю, включаю) или включенное образование - термин, используемый для описания процесса обучения детей с особыми потребностями в общеобразовательных (массовых) школах. В основу инклюзивного образования положена идеология, которая исключает любую дискриминацию детей, которая обеспечивает равное отношение ко всем людям, но создает особые условия для детей, имеющих особые образовательные потребности. Инклюзивное образование - процесс развития общего образования, который подразумевает 
доступность образования для всех, в плане приспособления к различным нуждам всех детей, что обеспечивает доступ к образованию для детей с особыми потребностями.

Инклюзивное образование развивается на основе традиционной и специальной систем образования, объединяя их для потребностей лиц с ограниченными возможностями здоровья и инвалидностью. Для характеристики развития инклюзивного образования в системе высшего образования необходимо исследовать нормативно-правовые, системные, педагогические аспекты общего и специального образования.

В мировой практике, начиная с 1970-х гг., ведется разработка и внедрение пакета нормативных актов, которые способствуют расширению образовательных возможностей инвалидов.

В образовательной политике США и Европы развиваются несколько подходов:

- десегрегация школ, расширение доступа к образованию (widening participation);

- интеграция - приведение в соответствие потребностей детей с психическими и физическими нарушениями с системой образования;

- мейнстриминг (mainstreaming) - ученики с инвалидностью общаются со сверстниками на праздниках, в различных досуговых программах;

- инклюзия (от англ. inclusion - включение) - реформирование школ и перепланировка учебных помещений таким образом, чтобы они отвечали нуждам и потребностям всех без исключения детей.

В США в период с 1875 по 1914 гг. вводилось обязательное школьное образование, и были созданы классы для детей, считавшихся умственно недоразвитыми, а также для тех, кого полагали «неисправимыми за их поведение», глухих или физических инвалидов. В эти же годы Национальная ассоциация образования создала Департамент специального образования. Разрабатывались тесты измерения интеллекта, прибывали потоки иммигрантов, значительно выросло количество организованной рабочей силы, развивались психологические теории.

В 1962 году было предложено, а затем и усовершенствованно понятие каскада сервисов. Это модель для конструирования услуг по удовлетворению потребностей отдельных учащихся и ранжируется от обучения при больнице и домашнего обучения до спецшкол, спецклассов и, наконец, обычных классов массовой школы. В Законе 1977 года «Образование для всех детей-инвалидов» был приведен перечень соответствующих дополнительных услуг, которые необходимы для помощи детям-инвалидам в получении специального образования.

В 1990-е годы в США принимается закон об образовании для всех детей с инвалидностью, с его принципом индивидуализированного обучения, а также закон об образовании индивидов с инвалидностью. 
Исследования экономической эффективности инклюзивного образования, проведенные в 1980 - 1990-х гг. и демонстрируют преимущества интегрированного образования в терминах выгоды, пользы, достижений.

На сегодняшний день в большинстве западных стран сложился определенный консенсус относительно важности интеграции детей-инвалидов. Государственные, муниципальные и школы получают бюджетное финансирование на детей с особыми потребностями, и, соответственно, заинтересованы в увеличении числа учащихся, официально зарегистрированных как инвалиды.

Что касается системы образования в России, то в настоящее время она имеет достаточно широко представленные элементы инклюзии, так как включает в себя следующие варианты образования:

- формальное (с получением документа);

- неформальное (по интересам людей);

- информальное (общение, чтение) образование.

Образование в них носит по сути своей инклюзивный характер, то есть характер активного включения в образовательный процесс. В России, как и в каждой стране, имеется нормативно-правовая база, обеспечивающая в той или иной мере включенность всех категорий населения в образовательный процесс. Это дети и взрослые, люди с ограниченными возможностями, мигранты, родители, инвалиды, безработные, осужденные и освобожденные из мест заключения, молодежь и пенсионеры и др.

Подводя итог, хочется отметить, что идея инклюзивного образования необходимая и полезная для всех участников образовательного процесса. Но мы считаем, что у родителей должна оставаться альтернатива. Пусть родители «особенных» детей сами решают, какой образовательный маршрут выбирать для своих чад. А, педагоги всех образовательных учреждений разных типов (дошкольные, школьные, внешкольные, средние и высшие профессиональные, учреждения дополнительного образования и повышения квалификации и др.), должны помочь тем, чтобы максимально разъяснить особенности и расширить пространство образовательных возможностей и вариантов. 


\section{Литература}

1. Материал подготовлен на основе информации из открытых источников. 